УДК: 72.012.23; 904:725.942.(497.7)

ББК: 85.133(0)32

A43

DOI: $10.18688 / \mathrm{aa} 177-1-16$

Nade Proeva

\title{
Non-Figural Motifs on the Roman Funerary Stelae from Upper Macedonia (Problems of Dating and Interpretation)
}

Most artefacts in prehistoric and ancient times were created for practical purposes, and therefore the term techne - craft was used for all types of art objects until late Hellenistic times. From the perspective of the aristocratic circle, the craftsmen (slaves - servi, freedmen - libertini, and metoikoi) were seen as humble members of society, working for the needs of others. But the utilitarian purpose of artefacts did not prevent craftsmen from expressing their artistic perceptions, depending to a greater or lesser extent on their skill and talent.

Since the roots of Classical archaeology stem from collecting ancient art objects ${ }^{1}$, attention of the early researchers was focused primarily on them. Even today, in a survey text on Greek and Roman art, paintings and sculptures are emphasized above all other art forms. It was common for almost every ancient artefact to be evaluated from an artistic point of view, which is an elitist approach. Therefore, the older studies favoured artefacts with greater artistic value, while objects with less significant artistic qualities found in Roman provinces were totally neglected.

An excellent example of this approach is the group of gravestones whose original and primary purpose was marking the tomb, followed by a religious commemorative aim; thus different styles and types of monuments were developed. The gravestones set up on the slopes of the mountains in the valley along the middle course of the Vardar river (ancient Axios), from (Titov) Veles in the North to Demir Kapija in the South (Republic of Macedonia), have a very specific iconographic composition and style. They were therefore named the Kavadarci type stelae, after the biggest town in the region, but the name of Tikveš type stelae is much more appropriate $^{2}$. This type of stelae with non-figural and stylized motifs shown in the relief zone: both in the relief field and in the pediments are very rare in other parts of Macedonia. Apart from this unusual kind of motif, we have specific types of stelae with a relief field in the form of an arch or arched niche on the columns shown in the relief field. The stelae with two relief fields were rare in Macedonia, and always displayed figural motifs in the upper field, and non-figural ones, mostly agricultural tools, in the lower one [10, ill. II] (Fig. 1, Table of types).

Antiquarianism led to Archaeology as a science.

Registered by Nikola Vulić before World War II, therefore collected and stored in the Skopje Museum, and after the war in the local museums of (Titov) Veles, Kavadarci, Negotino, etc. 


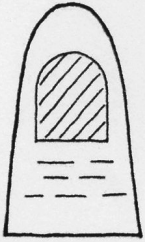

'I I
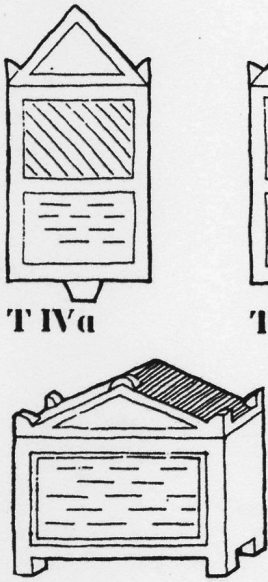

'T VI

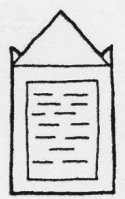

'I' II

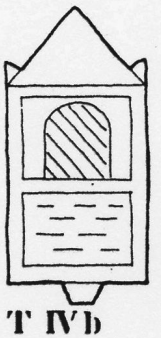

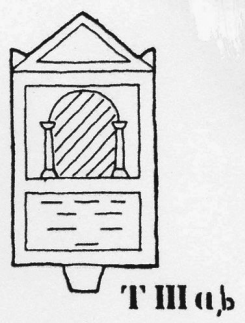

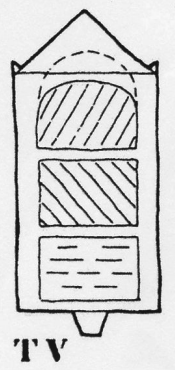

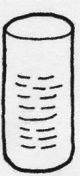

T' VIII

\section{E्] Inscription \\ ¿II Champ à relief aux motifs afiguratifs \\ EUA Champ à relief avec motifs figuratifs}

Fig. 1. Table of Tikveš types stelae

Motifs as well as human figures are stylized and simplified to the extreme; this is the main feature of these stelae. The figures of the deceased on these stelae are carved in a very shallow relief without the third dimension or carved in outline; the folds of clothing, facial features and sometimes the whole figure are displayed with notches. Anatomical details are generally also rendered by incision rather than by modelling. It must be kept in mind, however, that these stelae were carved by unskilled and uneducated local craftsmen (the inscriptions include numerous linguistic errors). In addition, it should be pointed out that the local stone (gneiss, volcanic tuff, andesite, etc.) was unsuitable for polishing, which contributes to this very specific style. Such a "naïve" style is typical of Late Antique art, and that is why these stelae have sometimes been dated to Late Antiquity. The deceased on the stele from Kavadarci (Fig. 2) [31, no. 149] were interpreted as saints, although the epitaph ends with a pagan greeting formula for the passer-by, and the stele was dated to Byzantine times [28, p.318, no. 46]. The same motif, a stylized vine tendril above the heads of the deceased, can be seen on another stele found in the 
vicinity of Kavadarci (Fig. 3) [34, no. 141]. Almost all epitaphs on the Tikveš type stelae end with a banal, pre-Christian formula, mnemes harin, which is one of the most frequent pagan funerary formulas, common in Roman times. Given that these stelae have neither Christian nor crypto-Christian elements, such dating and interpretation are ill-founded, not to say absurd. Several dated stelae of this Tikveš type [22, pp. 101-107] unequivocally demonstrate that their stylization and oversimplification cannot be used as a unique element for chronology. So far, only one of these stelae was found during the excavation of the Roman necropolis near the village of Resava. This stele was used secondarily, built into a tomb dated back to the late $2^{\text {nd }}$ or early $3^{\text {rd }}$ century $\mathrm{AD}[23$, p. 683 , no. 10$]$, which means that the stele should be dated back no later than to the first half of the $2^{\text {nd }}$ century AD. The earliest stelae of Tikveš type date back to the $1^{\text {st }}$ century $\mathrm{AD}$, the latest ones are from the $4^{\text {th }}$ century $\mathrm{AD}$ and few in number, while most of the stelae belong to the $2^{\text {nd }}$ and $3^{\text {rd }}$ centuries $\mathrm{AD}$ [22, pp. 101-107]. Christian monuments in Macedonia were rare until the $4^{\text {th }}$ century, being scarce even in Stobi, where a paleo-Christian basilica from the late $4^{\text {th }}$ century AD proves the presence of Christians. Moreover, the Christian stelae have a completely different iconography: usually only a cross is depicted, and a very short epitaph begins with a formula, enthade keite - here lies. So, it is evident that on these two stelae from Kavadarci we have a stylization of the motifs, which confused scholars in respect to the dating as well as the interpretation of these stelae. Such stylization, though rare, is found in other provinces of the Roman Empire (e.g., Iberia, Dacia etc.). This kind of stylization is found in art of all historical periods from very distant regions, as it is evident from the examples of building tiles with grape and vine scrolls from the Buddhist temple of Nara, $7^{\text {th }}$ century AD.

On the Tikveš type stelae we find three groups of motifs taken from the real world of this region.

1. Vegetal (trees and plants): evergreen trees, human figures shaped as pine trees, pine cone on an altar (ara); grapevine tendril, laurel and ivy leaves, and rosettes.

2. Agricultural tools: hook for gathering grapes, pickaxe, and the reaping hook.

Fig. 3. Funerary stele from Kavadarci region, $3^{\text {rd }} / 4^{\text {th }}$ century AD, Archaeological Museum, Skopje, R. Macedonia

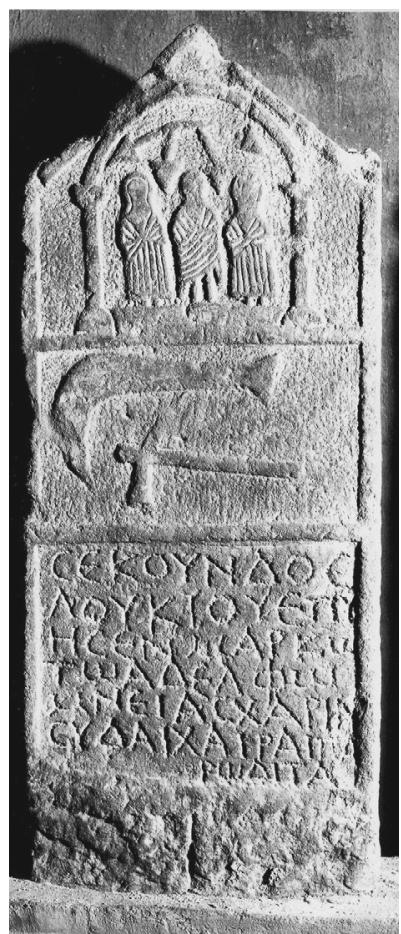

Fig. 2. Funerary stele from Kavadarci, $3^{\text {rd }}$ century AD, Archaeological Museum, Skopje, R. Macedonia

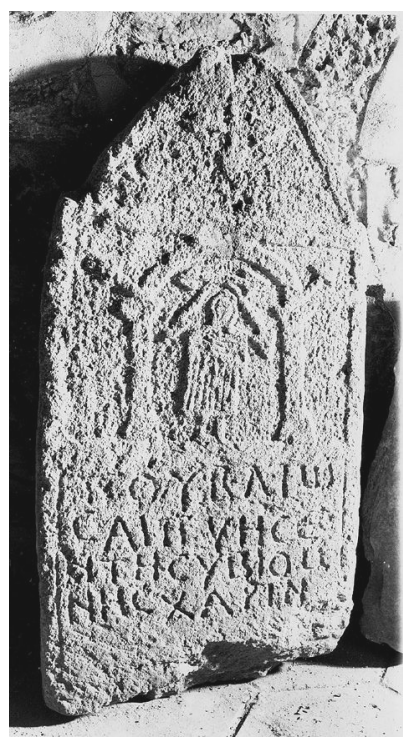




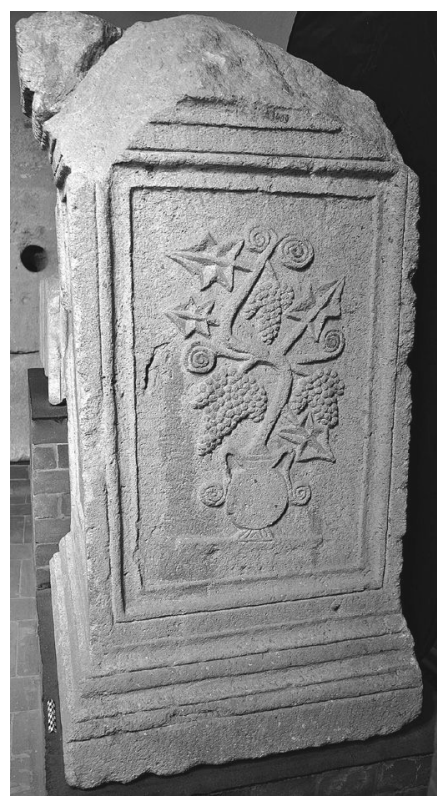

Fig. 4. Votive altar from Apulum (Alba Iulia), end of $2^{\text {nd }}$ century $\mathrm{AD}$, Museum Brukenthal, Sibiu, Romania
3. Astral: half-moon, stars with or without a half-moon ${ }^{3}$.

This unusual style consisting of lines, circles, arrow-shaped leaves, thick linear ornament, etc., unique to the Roman world, puzzled scholars. Sometimes it is not easy to understand the whole image, because the meaning of the motif often oscillates between ambivalence and ambiguity, or how and why the concept of this abstract portrayal of the human figure was created or where this concept of design originated from.

Until now scholars have expressed several opposing and conflicting interpretations and sharp definitions.

The first interpretation was that the motif of evergreen tree represents the survival of the Celtic tree cult $[8$, p. 217; 9, p. 111]. This is unlikely since neither the traces of the cult of any Celtic deity or any Celtic name has been witnessed in this region, nor any Celtic imitation of the coins of Macedonian kings, which are so common in areas north of Macedonia has been found.

The second interpretation was that an Attis-pine was depicted, i.e. that the pine cone was a substitute for the head of Attis [15, pp. 5, 7-8]. According to one version of the legend, Attis was transformed into a pine, carried into the shrine and mourned by the pilgrims during the Arbor intrat holiday on March 22 (Ovid, Metam. X, 103-105). This interpretation is also unacceptable, because neither the cult of Attis has been witnessed, nor the so-called funerary Attis on funerary monuments has ever been found in Upper Macedonia.

Some scholars interpret the motif of the crescent as the influence of immigrants from Asia Minor, who presumably brought the cult of the god Men [12, pp. 182-186]. But there were no settlers from Asia in this area, and they were rare in the Roman province of Macedonia. The only Asia Minor ethnicon from Roman times in the Republic of Macedonia known so far was found on a stele from the vicinity of Prilep; the epitaph mentions Amara, a city in the province of Arabia Felix [31, no. 457]. Neither the cult of Men, nor theophoric names derived from the name of the deity are witnessed. Of course, crescent is not an attribute of Men only, but of other deities such as Selene, Artemis, Dioskouroi, etc. as well.

Last but not least, we have to mention the Manichaean theory [6; 7]. According to this opinion, the deceased were followers of Manichaeism and the stelae gratuitously dated to the $3^{\text {rd }}$ and $4^{\text {th }}$ centuries $\operatorname{AD}[6$, p. $3 ; 7$, p. 19]. This is also quite unacceptable, because our sources do not mention the Manichaeans in Macedonia. For the Balkans, the Manicheans are mentioned three times in written sources [2, pp.521-523; 3, pp. 345-482]. So far, the only archaeological monument from the Balkans found in Salona near Split, the Roman province of Dalmatia, is

3 In this paper I am dealing only with motifs of the first and second groups. 
the epitaph of Lydian Bassa, which dates back to the mid- $4^{\text {th }}$ century on the basis of palaeography [29, no. 2245]. Here I will mention one very illustrative example - a votive altar from Apulum (Alba Iulia) (Fig. 4), erected by a Roman citizen, C(aius) C(aerellius S(abinus), who was Augustus legatus of the legion Tredecim Geminae, dedicated to Iunoni Reginae Populoniae, deae patriae. The epithet of Juno derived from the Etruscan city of Populonia certainly indicates the origin of the dedicator [16, no. 107]. The inscription shows that this monument dedicated to the goddess Juno, as well as the funerary inscriptions on the Tikveš stelae, can in no way be connected to Manichaeans, as was stated lastly [6, pp.3-70; pp. 21-87].

These conclusions were reached by scholars who analyzed the motifs separately, isolating "ornamental" elements or "pulling them out" from the iconographic composition and thus creating typologies of motifs; this is a formalistic approach. Analyzing the stelae only on the basis of an isolated particular iconographic motif disregarding other elements like inscriptions, onomastic formulas, names of the deceased and palaeography, is an incorrect method that prevents us from grasping the meaning of their iconography. Names of the deceased show not only their ethnic origin (autochthons, Roman colonists, immigrants from the East, etc.), but also their cultural background, which is important for understanding the iconography belonging to certain socio-cultural environment in which a stelae was created; this is an iconographic and anthropological approach.

Till mid- $20^{\text {th }}$ century, among scientists the opinion prevailed that every motif depicted on tombstones had some symbolic meaning, overemphasizing the cultural and social meaning of motifs. This symbolic approach may be described as romantic, i.e. an idealistic trend. After that, a different methodological approach was applied, ascribing only an ornamental, decorative value to the motifs; this rationalistic interpretation is a positivist trend. However, application of the new scientific method made it clear that both of these approaches were incorrect, and that the motifs may have had both a decorative and a symbolic meaning. The motif in itself is integral to the image and contributes to the constitution of the iconographic image; the choice and placement of ornament was never haphazard. This meant that the analysis must take into account more than a mere assemblage of lines and abstract shapes. A full and true interpretation can be reached only if the motifs are examined in the context of the iconographic composition as a whole, and its broader visual field is analyzed with the aim of understanding the image itself, its semantic weight, and finally the cultural and economic circumstances from which these stelae originate must be considered.

The main feature of the Tikveš type stelae is their extreme oversimplification, which is largely due to the kind of stone used. In the gables of two stelae from the region of Kavadarci [31, no. 163; 34, no. 136] and one from the village of Kanatlarci [34, no. 352] near Prilep, a circle with three leaves stylized in the form of 'arrows' is shown. Clearly this is a plainly styled rosette with leaves as can be seen when compared, firstly, to the less stylized display in the gables of a stele from the region of Kavadarci, rightly described by Vulić as a rosette and leaves in the corners [34, no. 155], and, secondly, to the less stylized rosette without leaves displayed in a circle on the stele from Vataša [31, no. 137]. From less stylized representations of these patterns it is clear that we have to deal with schematization. This was demonstrated by the late Professor A. Jovanović. Expertly analysing [10, pp. 513-516] the motifs on the pediments of two stelae, one from the North-Eastern border of the territory with stelae of Tikveš type [33, no. 64; 34, 


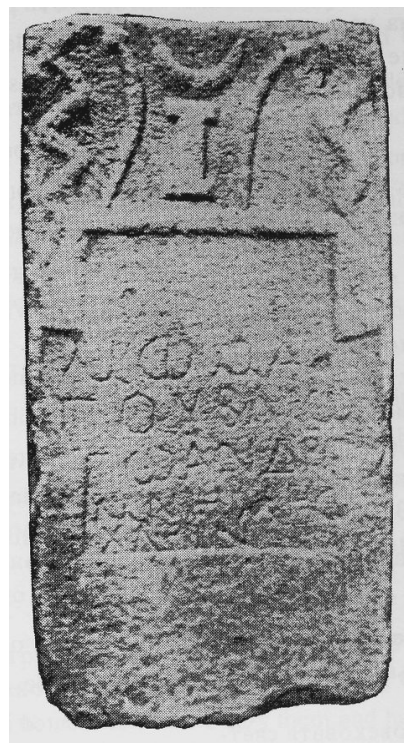

Fig. 5. Funerary stele from Krušica, $2^{\text {nd }} / 3^{\text {rd }}$ century AD in the church of St. Savor

photo on p. 279] (Fig. 5. Village of Krušica), and the other from Heraclea Lyncestis, modern day Bitola [31, no. 32] (Fig. 6), he proved that the iconographic scheme, and the motifs were not Manichaean. Comparison of these two stelae clearly shows that both expressed the same iconographic scheme - carved realistically on the stele from Bitola, and executed simplistically, beyond recognition, on the stele of Krušica [24, p. 104; 23, pp. 693-697]. Another example of simplification from the Tikveš region is the stele from Dolni Disan [24, p. 105, fig. 12; 23 , p. 702 , fig. 12]: a motif in the gable should be recognized as acanthus, not as a vulva [6, pp. 38-39; 7, pp. 48-49], which is evident from the less stylized representation on another stele from the same region [34, no. 131] (from Kavadarci).

A grapevine tendril with leaves is the most common motif on these stelae. Stylized grapevine tendril is shown on several stelae of the Tikveš type [31, no. 148; 34, no. 140]. The examples with less stylized motifs are also found as it is the stele from the vicinity of Kavadarci [32, no. 88]. Presenting grape vine in this kind of iconographic composition evidently had a symbolic meaning. Stylized vine tendrils shown over the heads of the deceased are actually the wreaths used by the worshippers of Dionysus for adornment. Even the capitals of the arches [34, no. 141] under which the deceased are shown (Fig. 3, Kavadarci) are decorated with branches of vine or laurel, the standard symbols of Dionysus. Even the god himself was represented with a vine tendril on his head [5, p.120, fig. 174, p. 121, fig. 175] or holding grapes in his hand. As a god of wine and vegetation who was constantly renewed, from very early times Dionysus was associated

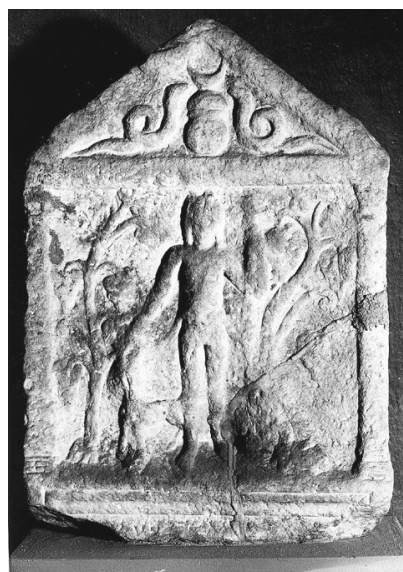

Fig. 6. Funerary stele from Bitola, $2^{\text {nd }}$ century AD, Archaeological Museum, Skopje, R. Macedonia with belief in the afterlife. As the imperial period progressed, mystery religions, especially Dionysian-Orphic mysticism with its promise of salvation, gained in popularity and became the paradigm of a mortal attaining immortality. Therefore, all kinds of funerary monuments bear its symbols: e.g., stelae [4, p.61, fig. 92; 34, no. 82; 31, no. 174], sarcophagi, ostothekes [11, fig. 18]. The heroized deceased were represented as Dionysus, often with pruning hook in hand, as is the heroized Antinous [26, pp. 144-145; 23, p. 691, fig. 9]. The two already mentioned stelae are the clear evidence that we have to deal with heroization of the dead in the form of Dionysus expressed in two different ways: realistically on the Bitola stele, and in a highly schematic fashion on the stele of Krušica [24, p. 104; 23, pp. 693-697; 26, p. 145].

In contrast to the grapevine tendril, displayed most often in the pediment of the stelae, the agricultural tools are always displayed in the lower relief field. This is understandable for 
a wine producing region. In the upper field there are figures of the deceased whose occupation is not indicated in the epitaph, as was usual in the Roman period, especially in the Western Roman provinces: the dead were often portrayed working with appropriate tools. On our stelae the profession of the deceased is expressed visually by depicting wine growing tools - pruning hook, pickaxe, thorn pick, and reaping hook. Shown beside a pruning hook (falx vinitoria), the pick has no symbolic significance of ascia, but indicates profession. When shown with agricultural tools, the grapevine tendril is also a sign of profession and has no symbolic meaning.

Especially original is the iconographic composition displaying trees, which is unique in the Roman world but typical of the population of the Tikveš region. Evergreen trees (cypress, pine, etc.), as well as other plants and herbs (laurel, ivy), by the reason of their eternal greenery, had acquired a symbolic funerary meaning and were therefore used to decorate tombs and gravestones. They were planted in cemeteries around graves, especially those of the prematurely deceased, as is demonstrated by their epigrams [18, p. 288; 19, p. 142, no. 30], as well by ancient authors. First and foremost, we should mention Ovid who wrote: Funeris ara mihi, ferali cincta cupresse (Ovid., Trist. III, eleg. 13, v. 21). As a consequence of such beliefs, pilasters and columns in the relief field of the stelae were adorned with

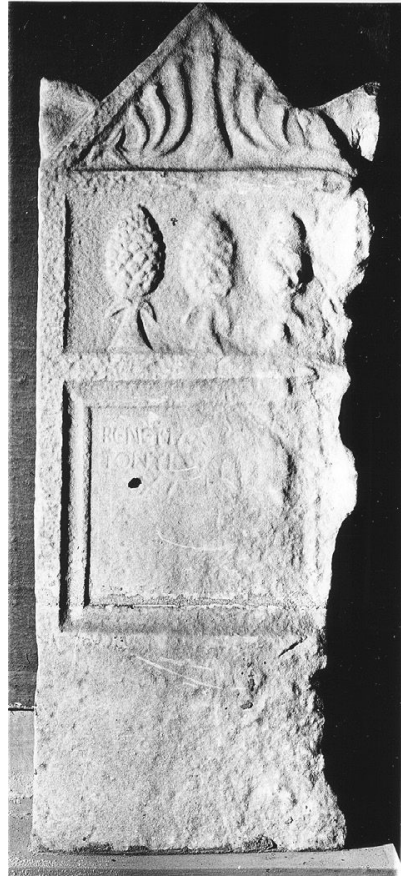

Fig. 7. Funerary stele from Volkovo, $3^{\text {rd }}$ AD. Archaeological Museum, Skopje, R. Macedonia shell of pine cone, as was the case with a stele from the village of Dolen Orman (now Laskarevo, Bulgaria) in the Pirin part of the Roman province of Macedonia [13, no. 2294]. It is also found in other provinces such as Dalmatia, Dacia, etc. [27, p. 177, fig. 3; 17, p. 144, pl. X; 5, p. 55, fig. 72, p.67, fig. 95]. The motif of the pine cone as a symbol of immortality is prevalent in the Roman world, much less so in the Greek world, except in Asia Minor. The most illustrative example is the so-called Barberini togatus dated to the end of the $1^{\text {st }}$ century BC, now kept in the Museo Capitolino in Rome [1, pp. 95-118]. An unknown Roman citizen is represented with two statues of his ancestors. In his left hand he is holding a bust, and with the right hand is embracing the shoulder of another bust placed on a pillar decorated with pine cone shell. This supports our interpretation that the schematic display of trees on the Tikveš type stelae is equivalent to the stelae of the so-called Prilep group (Pelagonia) with the figure of the deceased in the form of a pine tree [21, pp. 363-375, fig. 1-6]. (Fig. 7, stele from Volkovo). Namely, some stelae of this group have an arched pediment and the relief field displays the motif of a cone on a small altar, like stelae from the valley of the river Po [21, p.372, no. 49], indicating that the motif was brought by Italic emigrants, who settled in Stobi in the time of Caesar [14, pp. 213-237], but was modified and adapted to convey local beliefs. So, it becomes evident that on our stelae we see a display of heroized deceased and dead ancestors.

One stele with two relief fields displayed a trunk with three bare roots shown between two human figures (motifs of tree and figure constitute one another); the epitaph mentions the 


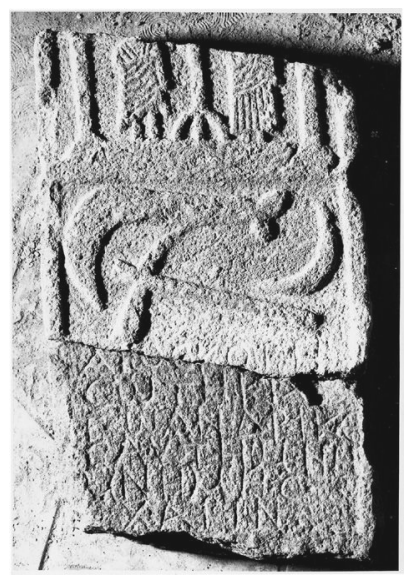

Fig. 8. Funerary stele from Kavadarci region, $2^{\text {nd }} / 3^{\text {rd }}$ century $\mathrm{AD}$, Archaeological Museum, Skopje, R. Macedonia

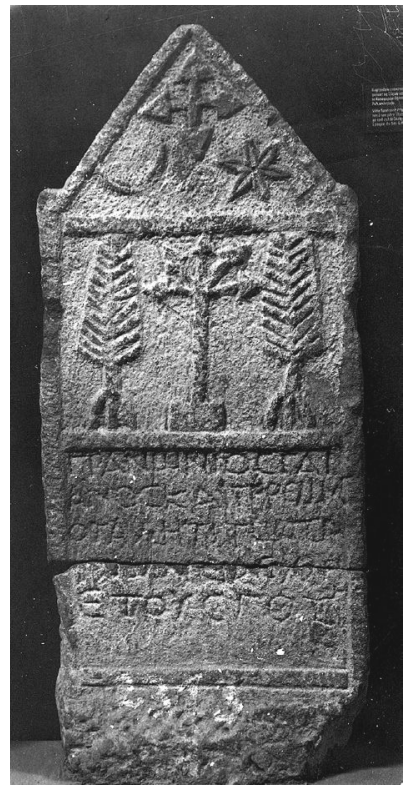

Fig. 9. Funerary stele from Kavadarci region, 325/6 AD, Archaeological Museum, Skopje, R. Macedonia couple [34, no. 134] (Fig. 8). Apart from the relief field, the deceased in a tree form are displayed in the gable of the stelae [34, nos. 137, 144], which in its turn is reserved for heroized ancestors. It is obvious that the display of a tree in the relief field symbolizes the heroized deceased, while trees in gable represent heroized ancestors [26, pp. 145-146, figs. 6, 7; 26, p. 153, figs. $8,9,11]$. We find the same iconographic pattern for heroization of a deceased and an ancestor expressed by the motif of a rider [26, p. 137, fig. $2 ; 25$, p. 151, fig. 2] or by busts [26, p. 138 ; 25, p. 151, fig. 3].

This kind of heroization is not usually found in the Roman world and we can positively say that it is typical of Macedonia, and that it reflects ancient beliefs preserved in legends. The most indicative is that of the couple Baukis and Philemon, who were the only ones to receive in their modest home and serve with food the gods Jupiter and Mercury (interpretatio romana for Zeus and Hermes) disguised as beggars. The next day the gods punished the inhabitants of Phrygia with a flood, while the modest hut of the couple was the only one spared and turned into a temple. The gods also fulfilled their wish to be priests of the temple and to die simultaneously. While dying, their bodies turned into an oak (Philemon) and a linden (Baukis) since then standing in front of the temple, where they were venerated (Ovid, Metamorphoses, VIII, $628 \mathrm{ff}$.). It is obvious that this is not a Greek legend but a Phrygian-Brygian myth in which the reasons for the flood are associated with the heroization of the two mortals, which is quite different from the Greek myth of the flood. If we recall that the Brygoi/Phrygoi were the oldest inhabitants in Macedonia, and thus a substratum in the ethnogenesis of the Macedonians, and that in Macedonia the Brygian enclaves were witnessed in historical times [20, pp. 80-114, 101-110], then the meaning of the trees shown on gravestones of the Tikveš type becomes much more comprehensible. This myth survived until the early common era, as can be seen from the welcome shown to Saul (St. Paul) and Barnabas, who were called Zeus and Hermes by the delighted people who were shouting: "The gods came to us in human form" (Acta Apostolorum, 14: 11-12). That we are really dealing with heroization of the deceased in the form of a tree, can be seen from several stelae with the deceased (often children) shown on a pedestal beneath the arch in the relief field [31, no. $148 ; 34$, nos. 109 , $137,140,147]$. These displays are thought to be the statues of the deceased. Consequently, the schematically depicted tree 
placed on a pedestal between two other trees with bare roots (Fig. 9) [34, no. 133] is actually a schematic image of a statue of a heroized ancestor, while the tree with bare roots symbolizes a heroized deceased. The other two trees shown with roots cannot be the symbol of Attis' dead body, or statues of the deceased, as was stressed above. The same iconographic scheme: a tree on a pedestal between two trees shown under an arch, include one stele, from the vicinity of Kavadarci $[18 \text {, p. } 286 \text {, fig. } 3 \text {, on p. } 293 \text {, wrongly marked as no. } 2 \text { instead of no. } 3]^{4}$. The incomplete inscription shows that the stele belonged to a native inhabitant.

The onomastic data recorded on these stelae show that the dead were mostly Romanized natives. Although they were under Roman influence and sometimes adopted someone else's motifs, they didn't copy them automatically. Instead, they processed and adapted them to their own beliefs. Even immigrants into Macedonia embraced the iconography of the natives. The seemingly unclear, naïve and simple iconography actually contains essential information about beliefs that survived the process of Romanization. It is a very original way of using specific symbolism to show heroization of the dead. The most commonly used motif, i.e. the grape vine, proves that this kind of praise of the deceased has a connection with the worship of Dionysus, one of the favourite divinities of the Macedonians.

To sum up, these unique stelae are important documents having an enormous importance for understanding the beliefs of the socio-cultural milieu in Roman Macedonia and the cultural interaction with other societies, both with those on the periphery and with cultural centres such as Rome.

\section{References}

1. Bandinelli R. Rome. Le centre du pouvoir. Lart romain des origines à la fin du deuxième siècle. Paris, Gallimard. Publ., 2010. 416 p. (in French).

2. Bratož R. Die Geschichte des frühen Christentums im Gebiet zwischen Sirmium und Aquileia im Licht der neueren Forschungen. Klio, 1990, 72, pp. 508-550 (in German).

3. Bratož R. Il cristiansmo aquileiese primo di Constanino, fra Aquileia e Poeovio. Udine; Goritzia, Istituto di Storia Sociale e Religiosa, Istituto Pio Paschini Publ., 1999. 535 p. (in Italian).

4. Cambi N. Imago animi. Split, Književni krug Split Publ., 2000. 443 p. (in Croatian and English).

5. Cambi N. Kiparstvo rimske Dalmacije (The Sculpture of the Roman Province of Dalmatia). Split, Književni krug Split Publ., 2005. 283 p. (in Croatian).

6. Čausidis N. Manihejskoto tolkuvanje na rimskite spomenici od t.n. "Kavadarečka grupa" (The Manichaean Interpretation of the Roman monuments of the "Kavadarci group"). Makedonsko Nasledstvo (Macedonian Heritage), 1999, IV/11, 3-70, reprinted in a Čausidis N.Dualistički sliki, pp. 21-77, with annex Analogii [analogies], pp. 79-87 (in Macedonian and English).

7. Čausidis N. Dualistički sliki. Bogomilstvoto vo mediumot na slikata (Dualistic Images: Pictorial Representation of the Bogomil Movement). Skopje, NIK List Publ., 2003. 440 p. (in Macedonian).

8. Čremošnik I. Narodna simbolika na rimskim spomenicima u našim krajevima (Popular Symbolism on Roman Monuments in Our Regions). Glasnik Zemaljskog Muzeja (Herald of the National Museum of Bosnia and Herzegovina in Sarajevo), 1957, 12, pp. 217-232 (in Serbo-Croatian).

9. Čremošnik I. Reljef Silvana i Nimfa iz Založja (Bihac) (Relief of Silvanus and the Nymphs from Založje (Bihac)). Glasnik Zemaljskog Muzeja (Herald of the National Museum of Bosnia and Herzegovina in Sarajevo), 1956, 11, pp. 111-123 (in Serbo-Croatian).

\footnotetext{
4 Vinčiḱ, 1996, p. $354=30$ wrote that it was unpublished, as well as Čausidis who refers to his publications instead of the editio princeps.
} 
10. Jovanović A. Arheološke beleške uz sakralne spomenike iz Makedonije (Archeological Notes on Sacred Monuments from Macedonia). Zbornik Narodnog Muzeja (Journal of National Museum). Beograd, 2005, 18-1, pp. 509-528 (in Serbo-Croatian).

11. Koch G. Sepulchral Sculpture of Roman Imperial Times in Albania. Funerary Sculpture of the Western Illyricum and Neighbouring Regions of the Roman Empire. Split, Književni krug Split Publ., 2013, pp. 837-864, fig. 1-36.

12. Medini J. Tragovi Menova kulta u Jugoslaviji (The Evidence from the Cult of Men in Yugoslavia). Godišnjak Centra za Balkanološka Ispitivanja (Annual of the Centre for Balkan Studies). Sarajevo, 1987, XXV/23, pp. 175-186 (in Serbo-Croatian).

13. Mihailov G. Inscriptiones Graecae in Bulgaria repertae, vol. 4. Sofia, Academia litterarum Bulgarica, Institutum Archaelogicum Publ., 1996. 343 p. (in Latin).

14. Papazoglou F. Oppidum civium romanorum et municipium Stobensium. Chiron, 1986, vol. 16, pp. 213-237 (in French).

15. Picard Ch. Sur quelques documents nouveaux concernant les cultes de Cybèle et d'Attis: des Balkans à la Gaule. Numen, 1956, vol. 4, pp. 1-23 (in French).

16. Piso I. Inscriptions d'Apulum (Inscriptions de la Dacie Romaine), III/5, Mémoires de l'Académie des Inscriptions et Belles-Lettres, 2 vols. Paris, Boccard Publ., 2001. 580 p. (in French).

17. Prijatelj K. Nekoliko rimskih nadgrobnih portreta u arheološkom Muzeju u Splitu (Several Roman Funerary Portraits in the Archaeological Museum in Split). Vjesnik za arheologiju i historiju dalmatinsku (Journal of Dalmatian Archaeology and History), 1950-1951, 53, pp. 135-154 (in Serbo-Croatian).

18. Proeva N. La stèle funéraire datée de l'année 325/6 de n.è. et les stèles de l'antiquité tardive de la région de Tikveš en Macédoine. The Age of Tetrarchs. D. Srejović (ed.). Beograd, 1995, pp. 284-293 (in French).

19. Proeva N. Stèles funéraires de la Haute Macédoine à lépoque romaine, étude typologique et iconographique. Mélanges d'histoire et d'épigraphie offerts à Fanoula Papazoglou. Beograd, 1997, pp. 141-147, pl. I-II (in French).

20. Proeva N. Studii za antičkite Makedonci (Studies about Ancient Macedonians), Historia Antiqua Macedonica, no. 5. Skopje, Macedonia Prima Ohrid Publ, 1997. 332 p. (in Macedonian).

21. Proeva N. Les stèles funéraires décorées de pins et de pommes de pin de Pélagonie en Haute Macédoine. Les ateliers de sculpture régionaux: techniques, styles et iconographie. Aix-en-Provence, Centre Camille-Jullian / Arles, Musée départemental de l'Arles antique Publ., 2009, pp. 315-327, pl. 1-5 (in French).

22. Proeva N. Sur la datation des monuments funéraires de Haute Macédoine, critères et difficultés. The Dating of Stone Monuments and Criteria for Determination of Chronology. Pula, Arheološci Muzej Istre Publ., 2014, pp. 101-107 (in French).

23. Proeva N. Sur l'iconographie des stèles funéraires du "type Tikveš" en Macédoine à l'époque romaine. Funerary Sculpture of the Western Illyricum and Neighbouring Regions of the Roman Empire. Split, Književni krug Split Publ., 2013, pp. 679-708 (in French).

24. Proeva N. Ikonografija na tikveškiot tip nadgrobni steli od rimsko vreme (Iconography of Tikveš type Grave Steles from Roman Times). Patrimonium (Patrimony), vol. III/7-8. Skopje, 2010, pp. 93-108 (in Macedonian).

25. Proeva N. Les croyances funéraires des Macédoniens: l'héroïsation et la divinisation des défunts à lépoque romaine. Cult and Votive Monuments in the Roman Province. Cluj-Napoca, Mega Publishing House Publ., 2015, pp. 149-160 (in French).

26. Proeva N. Heroizacija pokojnika u rimskoj provinciji Makedoniji (The Funerary Beliefs of the Macedonians: The Heroizing of the Deceased in Roman Times). Zbornik Narodnog Muzeja (Journal of National Museum), vol. 20-1. Beograd, 2011, pp. 129-155 (in Serbian).

27. Rendić-Miočević D. Nekoliko monumentalnih nadgrobnih stela sa portretima iz sjeverne Dalmacije (Several Monumental Tombstones with Portraits from Northern Dalmatia). Diadora, 1960, vol. 1, pp. 107-131 (in Serbo-Croatian).

28. Struck A. Inschriften aus Makedonien. Mitteilungen des Deutschen Archäologischen Instituts, vol. 27. Athenische Abteilung, 1902, pp. 305-320 (in German).

29. Šašel A.; Šašel J. Inscriptiones Latinae quae in Iugoslavia inter annos MCMII et MCMLX repertae et editae sunt, Series: Situla 25. Ljubljana, Narodni Muzej Ljubljana Publ., 1986. 533 p. (in Latin).

30. Vinchik' Ž. 1000 godini antika vo Tikvešijata (1000 years ancience $<$ sic $>$ periode in Tikveš area). Negotino, Opština Negotino Publ., 1996. 530 p., with summary in English, pp. 531-541 (in Macedonian). 
31. Vulić N. Antički spomenici naše zemlje (Ancient Monuments from Our Country). Spomenik Srpske Kraljevske Akademije, 1931, vol. 71, p. 509 (in Serbian).

32. Vulić N. Antički spomenici naše zemlje (Ancient Monuments from Our Country). Spomenik Srpske Kraljevske Akademije, 1933, vol. 75, p. 89 (in Serbian).

33. Vulić N. Antički spomenici naše zemlje (Ancient Monuments from Our Country). Spomenik Srpske Kraljevske Akademije, 1934, vol. 77, p. 104 (in Serbian).

34. Vulić N. Antički spomenici naše zemlje (Ancient Monuments from Our Country). Spomenik Srpske Akademije Nauka, 1941-1948, vol. 98, p. 339 (in Serbian).

Title. Non-Figural Motifs on the Roman Funerary Stelae from Upper Macedonia (Problems of Date and Interpretation).

Author. Nade Proeva - Ph. D., Professor Emerita. University Sts. Cyril and Methodius, Bul. Goce Delčev br. 9a, 1000 Skopje, Republic of Macedonia.nproeva@gmail.com

Abstract. Classical archaeology is deeply rooted in collecting works of art, and this is the reason why the earlier scholarly works focused on artefacts of high artistic value, while artefacts with less significant artistic qualities were totally neglected. An obvious example is a group of funeral stelae with non-figural iconography also known as Tikvesh type stelae spread in the valley alongside the middle course of the Axius (Vardar) River, Upper Macedonia. They display very specific motifs in their relief field as well as in the pediment, e.g. human figures shaped in evergreen tree forms, grapevines and ivy leaves, and rosettes, or agricultural tools (hook for picking grapes, pickaxe etc.).

They are dated from the $1^{\text {st }}$ to the $4^{\text {th }}$ century $\mathrm{AD}$, the largest number belonging to the $2^{\text {nd }}$ and $3^{\text {rd }}$ centuries AD. Neglecting the epitaphs and treating the motifs separately and out of context, scholars have reached widely differing interpretations: either that the iconography reveals Celtic beliefs, or that it is Oriental (based on the cults of Men, Attis and Cybele) or that it is Christian and Gnostic, i.e. of Manichean origin.

It is worth mentioning that no evidence for such interpretations has ever been found either in written sources, or even in archaeological materials. Dated monuments clearly show that their schematic "naïve" style is determined by the type of local stones (e.g., gneiss, volcanic tuff, andesite), which is unsuitable for polishing, and cannot be an element for chronology. Also these stelae were carved by the locals, who were pretty unskilled craftsmen.

Treating the iconographic composition as a whole, taking the epitaphs into consideration as an integral part of the stelae along with the socio-economic, religious and cultural milieu in which they were created, I have concluded that this unusual iconography was used to express heroization (the epithet héros often occurred in epitaphs) of not only the deceased, but also their ancestors, expressed in an original way, typical of the local population.

Keywords: Roman Macedonia; funerary stelae; iconography; non-figural motifs; heroisation of the deceased; oriental deities; Celtic survivals; Manicheans dogma.

Название статьи. Надгробные стелы с нефигурными мотивами в Верхней Македонии (проблема датировки и интерпретации).

Сведения об авторе. Проева Наде - Ph. D., почетный профессор. Университет свв. Кирилла и Мефодия, бул. Гоце Делчев, д. 9а, 1000 Скопье, Республика Македония. nproeva@gmail.com

Аннотация. В силу того, что античная археология уходит корнями в историю собирательства произведений искусства, ранние научные исследования были сосредоточены на артефактах высокого художественного уровня в ущерб памятникам более скромных достоинств, изучением которых ученые пренебрегали. Характерный пример памятников такого рода - группа надгробий с нефигурной иконографией, так называемые стелы Тыквешского типа, известные по находкам в долине среднего течения реки Аксьос (Вардар) в Верхней Македонии. В основном изобразительном поле и на фронтоне стелы украшены своеобразными рельефами в виде вечнозеленых деревьев, имитирующих человеческие фигуры, а также в виде виноградной лозы, листьев плюща, розетт или сельскохозяйственных орудий (крюков для сбора винограда, кирок и др.).

Датируются эти памятники широко - I-IV вв., но большая их часть относится ко II и III вв. Рассматривая изобразительные мотивы отдельно от эпитафий, вне целостного контекста, специалисты предлагали для иконографии Тыквешских стел совершенно различные толкования: от иконографических вариаций на темы кельтских верований или ее восточной интерпретации (основанной на мифах о Мэне, Аттисе и Кибеле) до ее происхождения из недр христианского гностицизма или манихейства. 
Стоит заметить, что ни одного свидетельства в пользу таких интерпретаций не было обнаружено ни в письменных источниках, ни среди археологических материалов. Датированные памятники убедительно подтверждают, что основания для сложения схематичного «наивного» стиля Тыквешских стел следует искать в особенностях местных каменистых пород (например, гнейсов, вулканического туфа, андезита), которые не поддаются полировке, что само по себе является датирующим признаком. Кроме того, эти стелы вырубались местными, не слишком искушенными в ремесле мастерами.

Рассмотрение иконографических и композиционных решений в их целостности, с учетом всего комплекса образовавших это единство составляющих, включая такие его неотъемлемые части, как содержание эпитафии, социально-экономические обстоятельства, в которых создавались стелы, окружающая религиозная и культурная среда, - привело автора к заключению, что столь оригинальная, необычная иконография, характерная для местного населения, служила цели символической героизации (эпитет héros «героический, геройский» часто встречается в тексте эпитафий) не только самого усопшего, но и его предков.

Ключевые слова: римская Македония; надгробные стелы; иконография; нефигурные мотивы; героизация усопших; восточные божества; кельтские пережитки; манихейская доктрина. 